\title{
New Forms of Accountability and EU-Governance
}

\author{
Mark Bovens \\ Department of Public Administration, Utrecht School of Governance, Utrecht University, \\ The Netherlands. \\ E-mail: m.a.p.bovens@uu.nl
}

As the European Union is turning into a polity, issues of accountability increasingly have found their way onto political and academic agendas. One recurring issue is whether these new multi-level forms of governance require new forms of accountability. The article explores the meaning of new accountabilities and whether these would help to overcome possible accountability deficits. Since accountability is an ambiguous and contestable concept, the contribution first analyses the concept and then narrows it substantially before discussing the meaning of these new forms of accountability, both theoretically and in practice. New forms of accountability are diagonal or horizontal in character and include accountability to administrative forums, to citizens, clients, and civil society. The conclusion is that new forms of accountability enhance policy learning and provide a series of formal and informal checks and balances but they are no alternative to traditional forms of popular control. We therefore need traditional and new forms of accountability regarding European governance.

Comparative European Politics (2007) 5, 104-120. doi:10.1057/palgrave.cep.6110101

Keywords: accountability; European Union; multi-level governance; traditional and new accountabilities

\section{Traditional vs New Forms of Accountability for EU-Governance}

Accountability has come to be considered a hallmark of democratic governance (Mulgan, 2003). ${ }^{1}$ It therefore comes as no surprise that, as the European Union is turning more and more into a polity (Van Gerven, 2005), issues of accountability increasingly have found their way onto the political and academic agendas (Arnull and Wincott, 2003; Harlow, 2002; Fisher, 2004). There is a growing concern that the shift from national, state-based policymaking to transnational and multi-level European governance is not being matched by an equally forceful creation of appropriate accountability regimes (Schmitter, 2000; Fisher, 2004, 496). Accountability deficits are said to be a key cause of the low public visibility and legitimacy of the EU (Scharpf, 1999; Arnull and Wincott, 2003, 1). The new 'constitution' tried to address some of these problems, but it is doubtful whether it would have also tackled the large and growing technocratic and intergovernmental arenas such as comitology, the European Council/Council of Ministers, as well as the many 
non-majoritarian agencies. While the ratification of the constitution remains highly uncertain after the negative referenda in France and The Netherlands, gaping accountability deficits may continue to exist and even grow, compromising the legitimacy of the European polity (Bergman and Damgaard, 2000; Curtin, 2004).

One of the recurring issues in the debates about accountability and EU governance is whether these new, multi-level forms of governance would require new forms of accountability. Traditional accountability arrangements, such as the doctrine of ministerial responsibility, have been based upon national institutions, such as national parliaments. The article tries to make sense of this debate about traditional vs new forms of accountability in the context of EU governance. It explores the meanings of 'traditional' and 'new' accountabilities and their potential to overcome accountability deficits for EUgovernance. It first analyses and then narrows the concept substantially, before discussing what the meaning of these new forms of accountability could be, both theoretically and in practice.

\section{The Meanings of Accountability ${ }^{2}$}

Accountability is a contestable concept par excellence. Anyone studying accountability will soon discover that it can mean many different things to many different people (Mulgan, 2000, 555; Behn 2001, 3-6; Dubnick, 2002; Pollitt, 2003, 89). Conveying an image of transparency and trustworthiness it is evocative and used in political discourse and policy documents. Moreover 'accountability' often serves as a conceptual umbrella covering various other often highly contested concepts. For example, the European Commission (2001, 2003) uses 'accountability' rather loosely. It serves not only as a synonym for 'clarity', 'transparency', and 'responsibility', but it is also equated with much broader concepts such as 'involvement, 'deliberation', and 'participation'. One of the reasons for this conceptual ambiguity and multiplicity is the fact that 'accountability' is an Anglo-Norman concept (Dubnick, 2002), which has no semantic equivalents on the European continent. Other languages, such as French, Portuguese, Spanish, German, or Dutch, have no exact equivalent and do not (yet) distinguish semantically between 'responsibility' and 'accountability' (Mulgan, 2000; Dubnick, 2002; Harlow, 2002, 14-15). In Germanic languages, such as Dutch verantwoordelijkheid is distinguished from verantwoording which resembles the contemporary distinction between 'responsibility' and 'accountability' in English. But even here, both obviously are semantically closely related, they are derived from antwoorden, and therefore closely connected to 'responsibility'.

The potential for conflict regarding accountability, therefore, does not lie just in the transplantation from one country to another, or in the decoupling of 
the customary from the organizational, as was observed in the introduction to this special issue. Part of the ambiguity and contestation is caused by the very fact that for most European politicians, lawyers and constitutional scholars, for whom English is a secondary language, accountability is a germane concept to begin with. Continental European constitutions may have provisions for responsibility, such as in the doctrine of ministerial responsibility, or for Rechenschaft und Verantwortung, but they have no explicit norms regarding 'accountability'. While for policymakers with experience in the Anglo-Saxon tradition accountability has been recognized as an organizing principle for a long time (see Wiener, 2007, Box 2), others are learning its meaning in practice. Contestation of the meaning of accountability therefore stands to be expected.

Secondly, within contemporary Anglo-American discourse, 'accountability' seems to be an ever-expanding concept (Mulgan, 2000). The term, to quote the Australian philosopher Richard Mulgan (2003, 8), 'has come to stand as a general term for any mechanism that makes powerful institutions responsive to their particular publics'. This may be well for political spinning, policy rhetoric, and white papers, but it makes the concept less suitable for systematic comparative, scholarly analysis. However, there is a pattern in the expansion.

In the American academic and political discourse, accountability is used predominantly as a normative concept, as a set of standards for the evaluation of the behaviour of public actors. Accountability or, more precisely, 'being accountable', is seen as a virtue, as a positive quality of organizations or officials. Hence, accountability studies often focus on normative issues, on the assessment of the actual and active behaviour of public agents (Dubnick, 2002; Koppell, 2005). Accountability in this very broad sense is basically an evaluative, not an analytical concept. It is used to positively qualify a state of affaires or the performance of an actor. It comes close to 'responsiveness' and 'a sense of responsibility', a willingness to act in a transparent, fair, and equitable way. Accountability in this broad sense is an essentially contested and contestable concept, because there is no general consensus about the standards for accountable behaviour, and they differ from role to role, time to time, place to place, and from speaker to speaker. ${ }^{4}$

In British, Australian, and continental European scholarly debates, accountability often is used in a much more narrow, descriptive sense. Accountability is seen as a social mechanism, as an institutional relation or arrangement in which an actor can be held to account by a forum (Day and Klein, 1987; Mulgan, 2003; Meijer and Schillemans, 2007). Here the locus of accountability studies is not the behaviour of public agents, but the way in which these institutional arrangements operate. And the focus of accountability studies is not whether the agents have acted in an accountable way, but whether they are or can be held accountable ex post facto by accountability 
forums. Both concepts, the broad one, in which accountability is seen as a personal or organizational virtue, and the narrow one, in which accountability is defined as a social mechanism, are very useful for the study of, and the debate about, democratic governance beyond the state. However, they should be distinguished, as they address different sort of issues and imply very different sort of standards and analytical dimensions.

\section{Accountability as a Relation between Actor and Forum}

This article focuses on the narrow concept of accountability. A debate about accountability and EU governance, using the concept in the broad sense, would in fact highly overlap with the related, but analytically quite different debates on the democratic deficit, on deliberative European policymaking, or on the even broader issue of good governance in the European Union. I will stay close to its etymological and historical roots - accountability comes from accounting - and define accountability as a relationship between an actor and a forum, in which the actor has an obligation to explain and to justify his or her conduct, the forum can pose questions and pass judgment, and the actor may face consequences. This narrow definition of accountability contains a number of elements. To qualify a state of affairs as a case of accountability, for the purpose of this paper, there should be an actor, either an official or an institution, who provides information about his or her conduct to a forum; there should also be explanation and justification of conduct - and not propaganda, or the provision of information or instructions to the general public. The explanation should be directed at a specific forum - and not be given at random. The actor must feel obliged to come forward - instead of being at liberty to provide any account whatsoever. Finally, there must be a possibility for debate and judgment by the forum, and the possibility of formal or informal sanctions or rewards - and not a monologue without engagement.

By using such a strict definition I narrow the playing field considerably. I will not take into consideration a number of phenomena that are sometimes presented as new forms of accountability. Transparency, for example, which is often used as a synonym for accountability, is not enough to constitute accountability as defined here. Open government and freedom of information are very important prerequisites for accountability in the context of European governance, because they may provide accountability forums with the necessary information. However, transparency as such is not enough to qualify as a genuine form of (narrow) accountability (Fisher, 2004, 504), because transparency does not necessarily involve scrutiny by a specific forum. Accountability as defined here should also be distinguished from responsiveness and participation (Mulgan, 2003, 21). The European commission, in its White Paper on European Governance and some of the documents following it, 
sometimes tends to blur accountability with issues of representative deliberation (Harlow, 2002, 185). It calls for more openness and a better involvement and more participation of a broad range of stakeholders in the EU policy process (European Commission, 2003, 35-38) in order to enhance the EU's accountability. However, accountability as it is defined here, is in nature retrospective. Actors are to account to a forum after the fact. Responsiveness to the needs and preferences of a broad range of stakeholders and new forms of consultation and deliberation may be very important to enhance the political legitimacy of the EU, but they do not constitute accountability per se. They provide proactive inputs into the policy process, but they lack the element of justification, judgment, and consequences. They should be discussed and studied separately for what they are: forms of consultation and participation. Similarly, there is a fine line between accountability and control. Some would equate accountability with controllability (Lupia, 2003, 35; Lord, 2004, 136-159). However, 'control', used in the Anglo-Saxon sense, is broader than accountability and can include both ex ante and ex post mechanisms of directing behaviour (Scott, 2000, 39). Control means 'having power over' and it can involve very proactive means of directing conduct, for example through straight orders, directives, financial incentives, or laws and regulations. But these hierarchical, financial, or legal mechanisms are not mechanisms of accountability per se, because they do not in themselves operate through procedures in which actors are to explain and justify their conduct to forums (Mulgan, 2003, 19).

Let me reassure the reader who may be wondering whether there is anything left to talk about. Even this narrow, retrospective definition of accountability, encompasses a great variety of accountability relations. Public institutions are frequently required to account for their conduct to various forums in a variety of ways. These accountability relations can be classified on the basis of three questions. The first question in relation to accountability is always: to whom is the account to be rendered? This will yield a classification based on the type of forum to which the actor is required to render account. In the case of political forums, one can speak of political accountability. In the context of EU governance, these could be a national parliament and in particular its standing committee on European affairs, the European Parliament and its subcommittees and commissions, voters in parliamentary elections or with referenda, and increasingly also the media. Courts, such as the Court of First Instance and the European Court of Justice, are legal forums that deal with legal accountability. Next to the courts, a wide range of quasi-legal forums exercising independent and external administrative and financial supervision and control has been established in the past decades. Examples of these forms of administrative accountability are the European Ombudsman, Office Européen de Lutte Anti-fraude (OLAF), and the Court of Auditors. ${ }^{5}$ 
A second, logical question is: who should render account? Who is the actor required to appear before the forum? In ordinary social relationships among citizens, it is usually clear whom the actor is who will render account. This is a far more complicated question to answer when it comes to public organizations. In legal procedures, it is often the organization as a corporate entity, which is held accountable. This can be called corporate or organizational accountability. An example of this is the accountability of member states towards the Court of Justice in case of violations of the treaty (Article $226 \mathrm{EC}$ Treaty). In most instances of political accountability, it is only the top of the organization that is called to account externally. This can be called hierarchical accountability. A clear example is the political accountability of ministers for civil servants in countries that have a parliamentary system. As we shall see, it is still being debated whether individual European commissioners are accountable for civil servants working in the commission. So far, there is at least a collective accountability of the commission as a whole to the European Parliament. Finally, in the case of individual accountability each individual official can be called to account on the basis of his actual contribution instead of on the basis of his formal position.

Another question regards that of why the actor feels compelled to render account. This relates largely to the nature of the relationship between the actor and the forum, and in particular to the question of why the actor has an obligation to render account. This will subsequently lead to classifications based on the nature of the obligation, for example obligations arising from a principal-agent relationship, a contractual agreement or which have been voluntarily entered into. This yields a classification based on spatial metaphors: vertical, horizontal, or diagonal accountability.

\section{What are Traditional and New Accountabilities?}

Having said all this about the contestable concept of accountability, the next question is: what could be meant by traditional and new accountabilities in the context of EU multi-level governance? The distinction between traditional and new is of course a matter of degree — today's traditions were yesterday's novelties. If one takes a narrow perspective on accountability for European governance, the distinction is first of all a distinction between vertical and horizontal accountability, or between actor-forum relations that have a principal-agent character and relations that do not have such a character. In western democracies the dominant public accountability relationships traditionally have been vertical and follow principal-agent relationships (Strom, 2000, 2003). Voters delegate sovereignty to popular representatives who in turn delegate the majority of their authorities to a cabinet of ministers. Ministers subsequently delegate many of their authorities to their civil servants or to 
various, more or less independent, administrative bodies. The mechanism of political accountability operates precisely in the opposite direction to that of delegation.

Over the past decades, this Weberian, or in Britain Diceyan, monolithic system of hierarchical political accountability relations has been under serious pressure in a number of national states and is slowly giving way to a more diversified and pluralistic set of accountability relationships. ${ }^{6}$ New mechanisms of accountability are diagonal or even horizontal in character and include accountability to administrative forums, to citizens, clients, and civil society. ${ }^{7}$ Also, more individual forms of accountability have been introduced to supplement hierarchical accountability. First of all, the rise of administrative accountability relations, through the establishment of ombudsmen, auditors, and independent inspectors, does not fit within the traditional top-down, principal-agent relationships. Although most of these administrative forums report directly or indirectly to Parliament or to the minister, they often do not stand in a hierarchical relationship to the actors. Some of them, such as ombudsmen, do not even have formal powers to coerce public actors into compliance - with the exception of Sweden (Ziller, 2001, 115). Most of these administrative accountability relations are a form of diagonal accountability, they are meant to foster parliamentary control, but they are not part of the direct chain of principal-agent relations (Magnette et al., 2003, 836). These controlling agencies are auxiliary forums of accountability that were instituted to help the political principals control the great variety of administrative agents, but gradually they have acquired a legitimacy of their own and they can act as independent accountability forums.

Secondly, accountability forums increasingly adopt individual strategies of accountability. They are not satisfied with calling only the agency or its minister to account, but also turn to individual officials. This rupture with the Weberian doctrine started in military and penal law in the Nuremberg and Tokyo Trials after the Second World War (Bovens, 1998, 122, 153). Nowadays, in many European countries individual civil servants cannot always hide behind their agency or their superiors and can be held accountable by civil courts or sometimes even by penal courts for their personal contributions to organizational misconduct. Parliamentary committees of inquiry are not satisfied with the official view of the department, and do not hesitate to summon individual civil servants to be questioned in their hearings (Barberis, 1998, 453, 466). In a similar fashion, it has been proposed to make DGs of the Commission directly answerable to the European Parliament (Mehde, 2003, 441).

Thirdly, the rise of quasi-autonomous or independent agencies has weakened the legitimacy of the Weberian and Diceyan systems of political control through the minister (Van Thiel, 2000; Flinders, 2001; 
Pollitt et al., 2001). In the case of these quangos, the traditional doctrine of ministerial responsibility is counterproductive. Although ministers formally remain answerable to Parliament for the daily performance of these agencies, they have far fewer powers of oversight and control than before. In many cases ministers have only retained a formal responsibility for policy formulation and institutional arrangements, whereas the operational responsibilities have moved to the heads of these agencies. In the absence of a political accountability of these agency heads, the agencies are effectively shielded from parliamentary scrutiny because the minister is structurally uninformed about their daily operations and will stand empty handed when questioned in Parliament about their performance. This political accountability gap partly explains the rise of legal and administrative accountability relations and causes a pressure for the creation of shortcuts to Parliament (Barberis, 1998). Hence, heads of autonomous agencies are sometimes made directly accountable to Parliament and may appear before legislative committees or they are being subject to administrative scrutiny bodies such as ombudsmen and national audit offices (Thatcher, 2002, 142). ${ }^{8}$

A similar development can be observed in the EU. Over the past decade, there has been a sharp expansion of the number and the powers of so-called non-majoritarian agencies in the EU. Traditionally, these agencies were established by the Commission and were assigned largely information gathering and coordination tasks. Newer agencies, however, include those with decision-making powers and the establishment of independent 'regulatory agencies' has been proposed by the Commission.' At the same time, the Council of Ministers has established a range of agencies (Europol, Eurojust, the European Defence Agency) with executive- and operational-type tasks. Deirdre Curtin (2006) has described the great diversity of new measures that have been installed to control these agencies. One of these novelties is the possibility for the European Parliament to summon directors of agencies.

Fourthly, the rise of New Public Management, which went hand in hand with the rise of quangos, has introduced more horizontal forms of accountability into the public sector. A variety of administrative reforms, that have been inspired by the private sector, such as the Financial Management Initiative and the subsequent Next Steps initiatives in the UK, or the reinventing government movement in the US, have tried to replace the hierarchical and bureaucratic logic of government operations with a contractual logic (Lane, 2000; Behn, 2001, 30-32; Pollitt and Bouckaert, 2005). Executive agencies have been turned into performance-based organizations (PBO), and are being evaluated on the basis of targets, performance indicators, and benchmarks, which have been laid down in (quasi) contracts (Behn, 2001, 123). These developments are not very prominent yet at the European level. This is partly because most of the execution of European 
policies and the delivery of public services is left to the national governments. The Commission itself does not provide many services to citizens and is mainly concerned with regulation, legislation, and the transfer of funds (Pollitt and Bouckaert, 2005, 236-237). However, this may also be because, to use an understatement from Pollitt and Bouckaert (2005, 233), the European bureaucracy has not been particularly receptive to management ideas that were not invented in Brussels. The Prodi-commission did introduce a series of more performance-oriented working methods when it reformed the commission (Commission, 2000, 2001). Most of these measures, however, did not follow a contractual, but a more traditional, hierarchical logic.

In the fifth place, partly in reaction to a perceived lack of trust in government, there is an urge in many western democracies for more direct and explicit accountability relations between public agencies on the one hand and clients, citizens, and civil society, including the media, on the other hand (McCandless, 2001; Meijer and Schillemans, 2007). The latter should become forums of political accountability, so the argument goes, and agencies or individual public managers should feel obliged to account for their performance to the public at large or to civil interest groups, charities, and associations of clients. This is called social accountability, because the accountability forums are located in the civil society (Malena, 2004). This would be horizontal accountability in the true sense, as the complete hierarchical chain, including Parliament, is surpassed and the agency, the minister, or the public manager is meant to be directly accountable to the citizenry. In the 1990s, many public agencies have established citizen charters, focus groups, and citizen panels to foster social accountability. ${ }^{10}$ Another example of social accountability are independent external evaluations of activities of a public agency. These evaluations have been conducted in some member states (Schillemans and Bovens, 2004) and are now introduced for European agencies as well. Quite a few of the recently established European agencies are subject to an independent, external evaluation every five years. In some instances, it is explicitly provided that the views of stakeholders and other interested parties will be taken into account and made public (Curtin, 2006, 107).

This proliferation of accountability relations has created intricate and opaque webs of accountability regimes in the public domain. The multi-level character of European governance has added another dimension to this, because public organizations may be held accountable both by national and by European forums (Scott, 2000, 51). Increasingly accountability forums seem to come together to form multi-level accountability networks, in which expertise and information is shared and in which European and national forums work together to hold European actors to account (Harlow and Rawlings, 2006). An early example is the ECJ conversing with national courts at the various 
stages of the legal accountability process. A more recent example of an emerging diagonal accountability network is the office of the European Ombudsman that is increasingly cooperating with national ombudsmen.

\section{Accountability Deficits in EU Governance: Three Perspectives}

What are we to make of these new, more horizontal forms of accountability? Can they help to limit accountability deficits in European governance? This means that we move from an empirical to an evaluative analysis. In order to get some grip on these complex normative questions, I make yet one more distinction. Accountability may serve various purposes with regard to public governance, and each of these purposes can function as a perspective for the evaluation of accountability arrangements and to identify potential deficits. In the academic literature and in policy publications three perspectives recur, albeit implicitly, time and again. Public accountability is important to provide a democratic means to monitor and control government conduct, it is important for preventing the development of concentrations of power, and, finally, to enhance the learning capacity and effectiveness of public administration. $^{11}$

Accountability matters from a democratic perspective as it makes it possible to call to account in a democratic fashion those holding public office (March and Olsen, 1995, 141-181; Mulgan, 2003). This approach reaches back to the tenets of Rousseau and Weber and has been theoretically defined using the principal-agent model. Hence, public accountability is an essential condition for the democratic process providing voters and their representatives with the information needed for judging the propriety and effectiveness of the conduct of the government (Przeworski et al., 1999). One major accountability deficit from this perspective is the political accountability of the Council at the European level. Neither the Council itself, nor its individual members are accountable to any political forum at the European level (Van Gerven, 2005, $85,91)$. Parliaments can try to hold their individual representatives to account at the national level — which may turn out to be increasingly difficult with the rise of qualified majority voting — but there is no collective political, let alone democratic, accountability of the Council as a whole.

For example, it has been argued that the rapid development of a European common foreign and security policy (CFSP) and a European security and defence policy (ESDF) have created serious democratic accountability gaps (Bono, 2002, ; Barbé, 2004; Lord, 2004, 189-195). The European Parliament cannot significantly scrutinize these activities, because they fall within the second pillar, and national parliaments have only limited possibilities to be informed of the proceedings and to hold their national representatives in the Council to account for the development of common defence policies. 
This differs for the Commission which nowadays is both collectively and individually accountable to the European Parliament. The European Parliament has a right to hear and interrogate commissioners, both orally and in writing, can establish temporary committees of inquiry, and eventually make the commission resign in case of gross misconduct (Van Gerven, 2005, 83-84). It can also force individual commissioners to step down by putting pressure on the president who since the Nice Treaty has the power to demand the resignation of individual commissioners - as was the case with Buttiglioni. However, constitutional scholars still debate whether the political accountability of individual commissioners to the European Parliament also extents to actions undertaken by their civil servants. Van Gerven (2005, 86-88) thinks individual commissioners should be accountable for civil servants, whereas Mehde (2003) thinks they are, de facto if not de jure, not accountable under the present legal and administrative arrangements.

Similarly, there are few political accountability arrangements provided for the various agencies that have been established by the Council and the Commission in the recent years. Although they may exercise very substantial regulatory or executive powers, neither the European Parliament nor national parliaments have the formal or factual powers to scrutinize them (Van Gerven, 2005, 91-97; Curtin, 2006). Some of them, such as the ECB, Europol, and the European Defence Agency, have been designed deliberately to evade political accountability (Harlow, 2002, 76). However, it may be that the European Parliament is making some inroads. It has been given the right in the contract design of some of the recently established agencies, such as the European Aviation Safety Agency and the European Agency for External Borders Operational Cooperation, to summon the executive director of the agency for a hearing on how the agency has been carrying out its tasks (Curtin, 2006, 106). The same lack of political accountability arrangements can be observed in the great variety of comitology committees, which allow administrators and experts to usurp powers that originally belong to Parliament. As Chris Lord has observed: 'Comitology slips through the net of a wide range of mechanisms of parliamentary scrutiny, and not just those of the EP' (Lord, 2004, 188). Finally, new modes of governance, such as the involvement of interested parties, experts, and civil society associations in EU-policy formation, decisionmaking and implementation, raise traditional questions of transparency and political accountability (Arnull and Wincott, 2003, 338-339). To what extent is it possible for voters or their representatives in the national or European Parliament to find out about and scrutinize what is going on in these new deliberative arenas and networks?

Another classic benchmark in the thinking about accountability can be found in the liberal tradition of Locke, Montesquieu, and the American Federalists (O'Donnell, 1999), to name but a few. The main concern underlying 
this constitutional perspective is that of preventing corruption and the abuse of state powers. The remedy is the organization of institutional countervailing powers. Other public institutions, such as an independent judicial power, are put in place next to the voter, parliament, and political officials, and are given the power to request that account be rendered over particular aspects. From this constitutional perspective, the picture is far brighter. The EU is held together by an elaborate, multi-level system of legal, financial, and administrative checks and balances. It has been a constant point of concern whether the Commission itself, as the major executive power within the EU, is not prone to corruption or other forms of administrative deviance. Much effort has gone into holding the European executive at bay. This has not been without success. Magnette $(2003,51)$ argues that the European Commission 'is one of the most controlled executives in the world. Situated between the Council and the Parliament, subject to the jurisdiction of the ECJ, watched over by the Ombudsman, the Court of Auditors and a series of ad hoc bodies, it is surrounded by mechanisms of control'. However, it remains an empirical question whether all of these formal mechanisms are effective in practice to hold the Commission at bay. Accordingly, the major source of concern would, again, be some of the newly established agencies, because they involve classic state monopolies: monetary powers in case of the ECB, policing powers in case of Europol and military powers in case of the EDA. These are the sort of executive functions that you want to have checked and balanced. Another possible locus of unfettered powers may lie again in the substantial role of experts in EU policymaking, particularly in the comitology procedures.

Thirdly, from a cybernetic perspective on accountability, the purpose of accountability lies also in maintaining and strengthening the learning capacity of the government (Aucoin and Heintzman, 2000, 52-54). Accountability is not only useful as a check, but it also leads to prevention. Public accountability offers a regular mechanism to confront officials and administrators with information about their own functioning and forces them to reflect on the successes and failures of their past policies (Luhmann, 1966). The second report of the Committee of Independent Experts, that was established to investigate allegations of fraud and corruption by the Santer Commission, fits within this perspective. In its second report, the committee formulated no less than 90 recommendations concerning the management and control of European governance, many of which eventually found their way into reform proposals (Van Gerven, 2005, 82).

\section{New Forms of Accountability and European Governance: Taking Stock}

These three perspectives cannot only be used to identify potential accountability deficits in European governance, they can also help to make more sense 
of some of these new forms of accountability. If we look at the various 'new' accountabilities from these three different perspectives, we see the following picture emerge. First of all, diagonal or horizontal forms of accountability do not of themselves enhance popular control of governance, because most of the forums involved are not democratic forums. Scrutiny by OLAF, by the European Audit Office or the European Ombudsman, is helpful to increase democratic control, but only if their reports and judgments are picked up by parliament, either at a national or the European level, to scrutinize actors at the European level. Several of these diagonal forms of accountability are part of the trend (Mair, 2005) to move away from popular control to more professional and technocratic forms of control. Similarly, social forms of accountability do not bring more democratic control in a strict sense. Accountability to the media or to citizen panels and civil society organizations is no full substitute for democratic control, because these forums are not elected. Furthermore, they can only exercise informal or indirect sanctions and do not have the power to vote the rascals out. But again, they can provide important inputs for the more traditional democratic forums of accountability.

However, these new forms of accountability are more promising from the other two perspectives. The establishment of administrative accountability forums, such as OLAF, the European Court of Audits, and the European Ombudsman, have been very important to establish a series of checks and balances on the exercise of European governance, both on the national and the European level. They create networks of formal and informal, multi-level accountability regimes that can help to keep the various executive bodies in check (Scott, 2000, 54; Harlow and Rawlings, 2006). Quite a few of the newly established European agencies, for example, are being subjected to a series of administrative, financial, and legal accountability arrangements that do not offer democratic control, but at least may effectively prevent them from becoming small Leviathans. (Curtin, 2006).

Social forms of accountability may be of help too in creating checks and balances. Monitoring of the EU executive by civil society organizations such as Statewatch or the European Civil Liberties Network, or public expenditure tracking by investigative journalists, may become increasingly important at the EU level to provide informal controls on the abuse of powers. The possibility of independent external evaluations of (some) European agencies is a very interesting innovation that rewards attention in the coming years. Both administrative and social forms of accountability also can be quite valuable from the learning perspective. Citizen monitoring and evaluation of public service delivery by independent agencies has been helpful at the national level to provide policymakers with feedback about the legitimacy and the effects of governance. It may well be that the new executive European agencies turn out 
to be important breeding grounds for new forms of accountability in this respect too.

The conclusion is, as always, that it is not a matter of either traditional or new forms of accountability. New forms of accountability can provide alleviations of some sorts of accountability deficits in EU governance, but certainly not of all. They may enhance learning and provide formal and informal checks and balances, but they are no alternative to traditional forms of popular control. However, they can at the least help to provide additional information for democratic forums. What we need regarding European governance therefore, are traditional and new forms of accountability.

\section{Notes}

1 An earlier version of this paper was delivered as a keynote speech at the Connex Mid-term conference, Mannheim, 4 November 2005. I like to thank Deirdre Curtin, Carol Harlow, Sonja Puntscher-Riekmann, and Antje Wiener for their valuable comments.

2 See for a more extended discussion of the concept of accountability Bovens (2006) on which most of this section is based.

3 In Dutch policy discourse 'accountability' is, therefore, often left untranslated because it is taken to stand for a broad, loosely defined trend towards a more managerial approach in the public sector. In Germanic languages the word rekenschap (Dutch) or Rechenschaft (German) would come closest to the original, auditory meaning of 'accountability'.

4 See Fisher $(2004,510)$ for similar observations about the use of 'accountability' in the European context.

5 See for the rise of administrative accountability in the EU: Harlow (2002, 108-143), Magnette (2003), Laffan (2003), and Pujas (2003).

6 See Bovens (2005), of which some of the following paragraphs are drawn.

7 See Day and Klein (1987, 10-29) for the general context; Barberis (1998), Flinders (2001), and Sullivan (2003) for the British context; see Bovens (2003, 46-67) and Meijer and Schillemans (2007) for the Dutch discussion. For an overview of the multi-level and composite character of accountability and control in the EU, see Harlow (2002), Costa et al. (2003), and Héritier (2003).

8 In Sweden, which has a much longer tradition of independent agencies, the Ombudsman has long been a key accountability mechanism. He/she has extensive powers to hold both agencies and individual civil servants to account. See Ziller (2001) for a comparison of this system with the hierarchical European model of political responsibility to Parliament.

9 See further details of the different types of agencies in existence: Report by the Working Group 'Establishing a Framework for Decision-Making Regulatory Agencies' (Group 3a). Preparation of Commission White paper on Governance, available at http://www.europa.eu.int/comm/ governance/areas/group6/report_en.pdf.

10 Note that most of these panels do not fully qualify as accountability arrangements in the narrow sense, for example as accountability forums, because there is no formal or informal obligation for the organisations to account for and justify their conduct, let alone a possibility for debate and judgment by these panels. At most these surveys can be used as inputs for other forums, such as parliament, supervisory boards, or the media, who then can hold public organizations to account. The Charter Mark assessments in Britain, in which public organizations volunteer for an extensive assessment of the quality of their public service delivery by independent Charter Mark Assessment Bodies, would probably come closest to horizontal accountability (Bellamy and Taylor, 1995; Duggett, 1998). 
11 The assessment of accountability arrangements, both with regard to national and European governance, cannot be disentangled from discussions about appropriate levels of democratic control, distribution of power, or reflexivity. Deficits only materialize against the background of standards that are explicitly, or implicitly embedded in notions about appropriate governance and national democratic and constitutional traditions (Fisher, 2004, 511-514).

\section{References}

Arnull, A. and Wincott, D. (2003) Accountability and Legitimacy in the European Union, New York and Oxford: OUP.

Aucoin, P. and Heintzman, R. (2000) 'The dialectics of accountability for performance in public management reform', International Review of Administrative Sciences 66: 45-55.

Barbé, E. (2004) 'The evolution of CFSP institutions: where does democratic accountability stand?' The International Spectator 2: 47-60.

Barberis, P. (1998) 'The new public management and a new accountability', Public Administration 76: $451-470$.

Behn, R.D. (2001) Rethinking Democratic Accountability, Washington, DC: Brookings Institution Press.

Bellamy, C. and Taylor, J. (1995) 'The new right conception of citizenship and the citizen's charter', Government and Opposition 30: 469-491.

Bergman, T. and Damgaard, E. (eds.) (2000) Delegation and Accountability in the European Union, London: Frank Cass.

Bono, G. (2002) 'Democratic accountability of military and police co-operation within the EU', Working Paper Series. PCAF Workshop on Parliamentary Oversight of International Military Cooperation/Institution. Geneva: DCAF.

Bono, G. (2004) 'The European Union as an International Security Actor: Challenges for Democratic Accountability', in H. Born and H. Hänggi (eds.) The Double Democratic Deficit, Aldershot: Ashgate.

Bovens, M. (1998) The Quest for Responsibility: Accountability and Citizenship in Complex Organisations, Cambridge: Cambridge University Press.

Bovens, M. (2003) De digitale republiek: Democratie en rechtsstaat in de informatiemaatschappij, Amsterdam: Amsterdam University Press.

Bovens, M. (2005) 'Public Accountability', in E. Ferlie, L. Lynne and C. Pollitt (eds.) The Oxford Handbook of Public Management, Oxford: Oxford University Press, pp. 182-208.

Bovens, M. (2006) 'Analysing and assessing public accountability: a conceptual framework, European Governance Papers No. C-06-01.

Commission (2000) 'Misc: Reforming the Commission: A White paper, Part I, Brussels, 5.4.2000.

Commission (2001) Implementing Activity Based Management in the Commission, Communication from the president in agreement with Mr Kinnock and Mrs Schreyer to the commission, Brussels, 25.07.2001: SEC (2001)1197/6\&7.

Costa, O., Jabko, N., Lequesne, C. and Magnette, P. (2003) 'Diffuse control mechanisms in the European Union: towards a new democracy?' Journal of European Public Policy 10/5: 666-676.

Curtin, D. (2004) Mind the Gap: The Evolving EU Executive and the Constitution, Third Walter van Gerven Lecture, Leuven Groningen: Europa Law Publishing.

Curtin, D. (2006) 'Delegation to EU Non-majoritarian Agencies and Emerging Practices of Public Accountability', in D. Gerardin, R. Munoz and N. Petit (eds.) Regulation Through Agencies in the EU: A New Paradigm of European Governance, London: Edward Elgar, pp. 88-119.

Day, P. and Klein, R. (1987) Accountabilities: Five Public Services, London: Tavistock. 
Dubnick, M.J. (2002) 'Seeking salvation for accountability, paper presented at the 2002 Annual Meeting of the American Political Science Association, Boston.

Duggett, M. (1998) 'Citizen's charter: a people's charter in the UK', International Review of Administrative Sciences 64: 327-330.

European Commission (2001) European Governance: A White paper, Brussels: European Commission.

European Commission (2003) Report from the Commission on European Governance, Brussels: European Commission.

Fisher, E. (2004) 'The European Union in the age of accountability', Oxford Journal of Legal Studies 24(1): 495-515.

Flinders, M. (2001) The Politics of Accountability in the Modern State, Aldershot: Ashgate.

Van Gerven, W. (2005) The European Union: A Polity of States and People, Oxford and Portland, Oregon: Hart.

Harlow, C. (2002) Accountability in the European Union, Oxford: Oxford University Press.

Harlow, C. and Rawlings, R. (2006) 'Promoting accountability in multi-level governance: a network approach', European Governance papers No. C-06-02.

Héritier, A. (2003) 'Composite democracy in Europe: the role of transparency and access to information', Journal of European Public Policy 10/5: 814-833.

Koppell, J.G.S. (2005) 'Pathologies of accountability: ICANN and the challenge of "multiple accountabilities disorder", Public Administration Review 65(1): 94-107.

Laffan, B. (2003) 'Auditing and accountability in the European Union', Journal of European Public Policy 10/5: 762-777.

Lane, J.-E. (2000) New Public Management, London: Routledge.

Lord, C. (2004) A Democratic Audit of the European Union, Basingstoke: Palgrave/MacMillan.

Luhmann, N. (1966) Theorie der Verwaltungswissenschaft: Bestandsaufnahme und Entwurf, KölnBerlin.

Lupia, A. (2003) 'Delegation and its Perils', in K. Strom et al. (eds.) Delegation and Accountability in Parliamentary Democracies, Oxford: OUP, pp. 33-54.

Magnette, P. (2003) 'Between parliamentary control and the rule of law: the political role of the Ombudsman in the European Union', Journal of European Public Policy 10/5: 677-694.

Magnette, P., Lequesne, C., Jabko, N. and Costa, O. (2003) 'Conclusion: diffuse democracy in the European Union: the pathologies of delegation', Journal of European Public Policy 10/5: 834-840.

Mair, P. (2005) 'Popular democracy and the European Union polity', European Governance Papers (EUROGOV) no. C-05-03.

Malena, C. (with Reiner Forster and Janmejay Singh) (2004) 'Social accountability: an introduction to the concept and emerging practice. Social Development Papers No. 76, Washington: World Bank.

March, J.G. and Olsen, J.P. (1995) Democratic Governance, New York: The Free Press.

McCandless, H.E. (2001) A Citizen's Guide to Public Accountability: Changing the Relationship Between Citizens and Authorities, Victoria B.C.: Trafford.

Mehde, V. (2003) 'Responsibility and accountability in the European Commission', Common Market Law Review 40: 423-442.

Meijer, A. and Schillemans, T. (2007) 'Fictitional citizens and real effects: accountability to citizens in competitive markets', Administration and Society, (forthcoming).

Mulgan, R. (2000) “'Accountability”: an ever expanding concept?' Public Administration 78: 555.

Mulgan, R. (2003) Holding Power to Account: Accountability in Modern Democracies, Basingstoke: Palgrave.

O'Donnell, G. (1999) 'Horizontal Accountability in New Democracies', in A. Schedler, L. Diamond and M.F. Plattner (eds.) The Self-Restraining State: Power and Accountability in New Democracies, London: Lynne Rienner Publishers, pp. 29-51. 
Pollitt, C. (2003) The Essential Public Manager, London: Open University Press/McGraw-Hill.

Pollitt, C., Bathgate, K., Caulfield, J., Smullen, A. and Talbot, C. (2001) 'Agency fever? Analysis of an international fashion', Journal of Comparative Policy Analysis: Research and Practice 3: 271-290.

Pollitt, C. and Bouckaert, G. (2005) Public Management Reform: A Comparative Analysis (2nd edn). Oxford: OUP.

Przeworski, A., Stokes, S.C. and Manin, B. (eds.) (1999) Democracy, Accountability, and Representation, Cambridge: Cambridge University Press.

Pujas, V. (2003) 'The European Anti-Fraud Office (OLAF): a European policy to fight against economic and financial fraud?' Journal of European Public Policy 10/5: 778-797.

Scharpf, F. (1999) Governing Europe: Efficient and Democratic? Oxford: Oxford University Press.

Schillemans, T. and Bovens, M. (2004) 'Horizontale verantwoording bij zelfstandige bestuursorganen', in S. van Thiel (ed.) Governance van uitvoeringsorganisaties: Nieuwe vraagstukken voor sturing in het publieke domein, Apeldoorn: Kadaster, pp. 27-37.

Schmitter, P. (2000) How to Democratize the European Union...And Why Bother?, Lanham: Rowman and Littlefield.

Scott, C. (2000) 'Accountability in the regulatory state', Journal of Law and Society 27(1): 38-60.

Strom, K. (2000) 'Delegation and accountability in parliamentary democracies', European Journal of Political Research 37: 261-289.

Strom, K. (2003) 'Parliamentary Democracy and Delegation', in K. Strom et al. (eds.) Delegation and Accountability in Parliamentary Democracies, Oxford: OUP, pp. 55-106.

Sullivan, H. (2003) 'New forms of local accountability: coming to terms with "many hands"?' Policy \& Politics 31/3: 353-369.

Thatcher, M. (2002) 'Delegation to independent regulatory agencies: pressures, Functions and contextual mediation', West European Politics 25: 125-147.

van Thiel, S. (2000) Quangocratization: Trends, Causes and Consequences, Utrecht: ICS.

Ziller, J. (2001) 'European models of government: towards a patchwork with missing pieces', Parliamentary Affairs 54: 102-119. 